\title{
English Songs as an Effective Asset to Improve Listening Comprehension ability; Evidence from Iranian EFL Learners
}

\author{
Samira Rahbar (Corresponding author) \\ Department of English Language \\ Science and Research Branch, Islamic Azad University, Guilan, Rasht, Iran \\ Tel: +989116385846 E-mail: rahbarsamira@gmail.com \\ Samaneh Khodabakhsh \\ Department of English Language, \\ Science and Research Branch, Islamic Azad University, Guilan, Rasht, Iran \\ Tel:+989125709144 E-mail: samaneh_khodabakhsh@yahoo.com
}

Received: 25-05-2013

Accepted: 08-08-2013

Published: 01-11-2013

doi:10.7575/aiac.ijalel.v.2n.6p.63

URL: http://dx.doi.org/10.7575/aiac.ijalel.v.2n.6p.63

\begin{abstract}
The present study has made an attempt to investigate the effectiveness of using English songs and lyrics on improving the listening comprehension ability of adult EFL learners in Iran. The participants of the study were selected based on their results in an OPT exam. 40 students whose score fell between 1SD below and above the mean were randomly assigned to two groups of control and experimental. At the beginning of the study a pre-test was run and the results of the groups were compared. The results didn't show any specific difference between the groups. Experimental group received treatment via listening practice by English songs for two months. By the end of the study a listening post-test was run and the result of the independent sample t-test showed a significant difference between the control and experimental group. The findings of the study indicated that listening to English songs can be an effective way to improve listening comprehension ability of EFL learners.
\end{abstract}

Keywords: English songs, listening comprehension ability, EFL

\section{Introduction}

Friedrich Nietzsche once said: "without music, life would be a mistake" $(1889$, p. 33). So why is that we EFL (English as a foreign language) teachers overlook the power of such handy instrument in our classes from time to time? Songs, combinations of music and lyrics, posses many intrinsic merits which render a valuable source for language learning and teaching (Shen, 2009). As song lyrics have many repetitive verses, their use can help L2 learners' skills by exposing them to forms, syntax, lexical items, segments and suprasegmentals (Abbott, 2002).

Among different language skills, listening comprehension ability is one of the most difficult ones to master, especially in an EFL context in which students are not exposed to the natural speech of native speakers and therefore are usually reluctant in attending listening classes. They complain that comprehending the native speakers' accent is difficult for them and as a result feel detached from authentic sources. In this situation, English songs can serve as an authentic material to enhance learners' listening skills (Kilickaya, 2004). Music lyrics can also make listening activities more fun and enjoyable. Learners feel attached to the beautiful and poetic versus and will feel more enthusiastic to carry on the listening session or even better to listen to the songs over again outside the classroom.

In our country Iran, however, teaching English has mostly been influenced by the traditional approaches in which songs and music have no or very little role in classroom instruction. In recent years only, songs have found their way to our classes as a result of using western course books. Their utilization is rare and limited to the course book's design. The present study aims at testing the effectiveness of using English songs in adult EFL classrooms in Iran.

\section{Literature review}

Human kind has always been interested in music and many EFL/ESL teachers have chosen to use music in their classrooms. Lazanov incorporated music in his method as it can relax students and stimulate their mental reserves (Laresen-Freeman, 2000).Several studies have indicated that songs can be used to facilitate learning different aspects of language (Ayotte, 2004; Fischler, 2006; Fisher, 2001; Neumam, 2004; Ransol \& Gilroy, 2001; Schon, Magne \& Besson, 2008; Sloboda, 1990, cited in Alipour, Gorjian \& Zafari, 2012). Lopera (2003) believes that including social contexts, the interaction with students' moods and feelings, and enhancing the availability of authentic texts in English are important reasons for incorporating songs into teaching contexts.

Moreover, in an EFL context where students are not exposed to the natural speech of native speakers, using songs as an authentic source according to Peacock (1997) can have a positive effect on learners' motivation. He recommends that teachers of adult EFL try appropriate authentic materials in their classroom, as they may increase their learners' levels of on-task behavior, concentration, and involvement in the target activity more than artificial materials (p.152). Lems 
(2001, cited in Beasley \& Chuang 2008) asserts that, through music, EFL students can learn the natural stretching and contracting of the normal stream of English speech (e.g., gotta vs. got to, I've vs. I have, and so on), which can assist them in developing more natural English conversation skills. Results of a study conducted by Beasley and Chuang (2008) on 169 Taiwanese EFL students revealed that both song likeability and song understandability significantly and positively influence learning environment enjoyment, which in turn significantly and positively influences learning perceptions.

Segura \& Villalba (2005, p. 70) wisely mention that using songs in classes can help EFL learners engage willingly in the listening activities, however, the interest of the students and the level of the class should be considered in choosing lyrics with appropriate complexity (cited in Neisa, 2008). Agustina and Puspawati (2008) also share their experience of using song worksheets containing pre-listening, while-listening and post-listening phases to evoke students' listening skills. In brief, they have made an effort to change the idea that listening activities are passive ones which should be done in laboratories as they usually are.

In 2009 Shen gave several reasons why songs can help English learning and thus should be used in EFL/ESL classes. Some of these factors include: Psychological implications, stimulation of affective learning and promoting language awareness.

More recently Alipour et al. in 2012 conducted a study on 105 Iranian male and female EFL students in Ahvaz, Iran to investigate the effects of songs on vocabulary learning. The participants listened to three different genres of music: pop, country, and rap. The results of the study suggested that songs are not merely an entertaining tool and can be used as a pedagogical material in EFL teaching.

Apart from a few attempts in the recent years, research about the notion of using English songs in EFL classrooms to facilitate different skills in general and listening skills in particular have somehow been neglected in Iran. Consequently this study has made an attempt to provide an answer to the question: Can using songs in EFL classes improve Iranian female EFL learners' listening skills?

\section{1 research question and Hypothesis}

Considering all stated above this research question can be stated as

- Does listening to English songs have any effect on adult EFL learners' listening ability?

Accordingly the null hypothesis of the research would be as follow

- Listening to English songs has no effect on adult EFL learners listening ability

\section{Method}

\subsection{Participants}

The study was conducted with 40 female Iranian students who had enrolled an EFL course in Kish Institute of Science and Technology in Rasht, Iran. The course consisted of 20 sessions, and students received 30 hours of general instruction. In order to make sure of homogeneity, participants were selected out of a pool of 200 based on their results in an OPT exam. Having calculated the mean and the SD, participants with the score of 1 SD above and below the mean ( $1 \mathrm{SD} \pm$ mean) were selected to conduct the study. All participants had already passed 10 courses in the same institute, apart from that, none had had any other experience of studying English. After selecting the participants the steps below were taken:

1. 40 students in the same level were selected randomly (randomization).

2. The participants were given a pre-test and their listening ability was scored.

3. The selected participants were randomly divided in two classes of equal number (random assignment). As stated previously each class included 20 participants.

\subsection{Material}

The materials used in this study were in four sorts:

1) Oxford Placement Test (OPT) which is a standardized Cambridge exam so reliability of the test is not needed to be tested

2) A listening comprehension test to determine the learners' listening ability. The test reliability was estimated 0.71 through Chronbach Alpha coefficient.

3) Songs which have been chosen based on their appropiacy culturally and academically.

4) Song worksheets designed containing pre-listening, while-listening and post-listening phases appropriate to the level of learners.

\subsection{Procedure}

As the study was conducted throughout a general English course, communicative Language Teaching was used in both classes and all methods, except for practice with music recordings, in experimental and control group were the same. In the control group learners received a normal routine instruction as they always do, whereas in experimental group in each session they were treated with listening to music recording for 20 minutes. The learners were also given some tasks to do with worksheets prepared from the lyrics of those recordings. During each session they had to listen to one song. The song was played for the first time while learners had been handed over a worksheet including some missing words. They listened to the song and filled the gaps. The second time they were given chances to check their answers and those who couldn't write for the first time had a chance to answer this time. After that, they were given the correct answers by their 
teacher. Finally they listened to the song again while reading their completed lyrics. They were given permission to sing at the same time along with the recording as well. By the end of the term which as previously mentioned takes almost 2 months that is 30 hours of input, the students in both groups were tested again. And the results were analyzed for further discussion via SPSS system.

\section{Results}

The data gathered from the post-test of the current study were analyzed via an independent T-test between the scores of experimental and control Group. The results are discussed below:

Table 1. Results of the comparison between the musical and non-musical groups

\begin{tabular}{lllllll}
\hline & Group & $\mathrm{N}$ & Mean & Std. Deviation & Std. Error Mean & sig \\
\hline \multirow{2}{*}{ Score } & Control & 20 & 13.6500 & 1.72520 & .38577 & 0.000 \\
& Experimental & 20 & 15.8500 & 1.81442 & .40572 & \\
\hline
\end{tabular}

As the table indicates the mean of the experimental group is significantly higher than that of the control group. However, as stated earlier at the beginning of the study the score of listening pre-test of the groups hadn't shown any difference. It means both groups had had similar listening comprehension ability at the beginning of the study. By the end of the study, however, the result of the listening post-test was as presented in table 1 . Therefore one can conclude that the treatment have been effective and listening to English songs as a class activity enhances learners listening comprehension ability. For more details table 2 is presented as follow;

Table 2. The summary of t-test between the posttest scores of experimental and the control group of the study

\begin{tabular}{|c|c|c|c|c|c|c|c|c|}
\hline \multicolumn{9}{|c|}{$\begin{array}{l}\text { Levene's Test for t-test for Equality of Means } \\
\text { Equality of } \\
\text { Variances }\end{array}$} \\
\hline $\mathrm{F}$ & Sig. & $\mathrm{t}$ & Df & $\begin{array}{l}\text { Sig. (2- } \\
\text { tailed) }\end{array}$ & $\begin{array}{l}\text { Mean } \\
\text { Difference }\end{array}$ & $\begin{array}{l}\text { Std. Error } \\
\text { Difference }\end{array}$ & $\begin{array}{l}95 \% \\
\text { Interval } \\
\text { Difference }\end{array}$ & $\begin{array}{l}\text { Confidence } \\
\text { of the }\end{array}$ \\
\hline & & & & & & & Lower & Upper \\
\hline \multirow[t]{2}{*}{.048} & .828 & $\begin{array}{l}- \\
3.930\end{array}$ & 38 & .000 & -2.20000 & .55984 & -3.33334 & -1.06666 \\
\hline & & - & 37.904 & .000 & -2.20000 & .55984 & -3.33343 & -1.06657 \\
\hline
\end{tabular}

According to table (2), the result of $\mathrm{t}$-test $\left(\mathrm{t}_{\mathrm{obs}}=3.93, \mathrm{p}<.05\right)$ yielded significant difference between the control and experimental groups. The obtained t-observed is higher than the critical value of $t$ in the $t$-student table with the degree of freedom of $38(\mathrm{df}=38)$ and the level of significance of $0.05(\mathrm{Sig} .=0.05)$ for the two-tailed (null) hypothesis as to be 2.o1. Such a result $\left(t_{\text {obs }}>t_{\text {crit }}\right)$ rejects the null hypothesis of the current study. In other words the retrieved sig from the study 0.000 is smaller than 0.05 so we can infer that the difference between the groups is significant.

\section{Conclusion}

Listening activities are among the most difficult ones in an EFL context, students are usually complaining that they cannot catch the words spoken by native speakers and are generally reluctant to do these activities. Using English songs in EFL classes, however, can bring about enjoyment and authenticity to the classroom atmosphere. Students in the experimental group tended to attend the listening activities more willingly and showed more enthusiasm in conducting the activities. As the result of the data analysis shows, the impact of English songs seems to be significant in students' improvement. Therefore, it can be inferred that such activities can bring new insight into EFL classes using available instruments for educational purposes. English songs seem to be an easy fun way of practicing different aspects of English. It has a significant effect on enhancing students' ability to comprehend listening texts. In our modern world in which everybody has access to songs easily, teachers can use this opportunity in order to improve their classes and to have more attentive and more successful learners. In EFL environments songs along with some worksheets can be prepared and applied so that learners can have access to authentic material which is on the other hand an interesting and enjoyable way of practicing English. Syllabus designers can include some songs in text books to improve the academic quality of the books as well as adding more flavor to the material learners study.

There is still room for further research in this regard. For instance the impact of songs on pronunciation ability or on other skills such as speaking can be investigated. Another area of investigation could be the relationship between the learner's favorite genres and its effect on enhancing their motivation and listening skills. It is hoped that this article could be a leading path toward new areas of research in order to open up new and innovative ways to teaching English. 


\section{Reference}

Abbott, M. (2002). Using music to promote L2 learning among adult learners. TESOL journal , 11.

Agustina, M. F., \& Puspawati, I. 2008. Workshop on Creating Fun Physical Activities for Listening in Adult Classes. Paper presented in the $6^{\text {th }}$ Asia TEFL conference held in Bali, 1-3 August.

Alipour, M., Gorjian, B., \& Zafari, I. (2012). The effect of songs on EFL learner's vocabulary recall and retention : The case of gender. Advances in digital multimedia , 1, 140-143.

Beasley, R. E., \& Chuang, Y. (2008). Web-Based Music Study: The Effects of Listening Repetition, Song Likeability, and Song Understandability on EFL Learning Perceptions and Outcomes. TESL-EJ , 12.

Kilickaya, F. (2004). Authentic Materials and Cultural Content in EFL Classrooms. The internet TESL journal , X.

Laresen-Freeman, D. (2000). Techniques and principles in language teaching. Oxford: Oxford University Press.

Lopera, S. (2003). Useful ideas when taking songs to a class. Íkala, 8(14), 135-149.

Neisa, C. M. (2008). Using Rock Music as a Teaching-Learning Tool. Profile issues in teacher's proffesional developement, 163-180.

Nietzsche, F. (1889). Twilight of idols. (D. Large, Trans.) Oxford, the UK: Oxford World Classics.

Peacock, M. (1997). The effect of authentic materials on the motivation of EFL learners. ELT journal , 51 (2), 144-156.

Shen, C. (2009). Using English songs: an enjoyable and effective approach to ELT. English language teaching , 2, 8894. 